\title{
Solid Phase 4'-Phosphopantetheinylation: Fungal Thiolation Domains are Targets for Chemoenzymatic Modification
}

\author{
Deirdre Stack, Aisling Frizzell, Karen Tomkins, and Sean Doyle*
}

National Institute for Cellular Biotechnology, Department of Biology, National University of Ireland Maynooth, Co. Kildare, Ireland. Received February 13, 2009; Revised Manuscript Received June 18, 2009

\begin{abstract}
No data exist on the ability of thiolation domains from fungal non-ribosomal peptide synthetases to undergo 4'-phosphopantetheinylation, using either biotinylated or fluorescently labeled coenzyme A analogues, mediated by 4'-phosphopantetheinyl transferases (PPTase). Yet, this is a key requirement to confirm the amino acid recognition function, and coding potential, of either non-ribosomal peptide synthetases or recombinantly expressed regions of these enzymes (e.g., didomains or modules). Moreover, determination of 4'-phosphopantetheinylation activity remains cumbersome. Here, we demonstrate that a recombinant fungal PPTase catalyzes the solutionphase transfer of either biotin- or fluorescein-labeled 4'-phosphopantetheine region of coenzyme A to a fungal thiolation domain, which is either part of a non-ribosomal peptide synthetase didomain (72 kDa), derived from Aspergillus fumigatus, or fused to a non-native protein (glutathione $s$-transferase). Significantly, we demonstrate that this reaction can unexpectedly occur when the target protein $(4.4 \mathrm{pmol})$ is immobilized on a solid surface. These findings (i) confirm that thiolation domains of fungal origin, in native or non-native configuration, can accept modified 4'-phosphopantetheine residues via PPTase-mediated labeling and (ii) illustrate a novel, highthroughput method to determine PPTase activity.
\end{abstract}

\section{INTRODUCTION}

Phosphopantetheinyl transferases (PPTase) catalyze the transfer of 4'-phosphopantetheine from coenzyme A (CoA) to the carrier domain of a range of enzymes involved in non-ribosomal peptide, polyketide, and fatty acid biosynthesis (1). Nonribosomal peptide (NRP) synthetases are produced in the inactive (apo-) form and are post-translationally modified by PPTase to the active (holo-) form by the covalent attachment of CoA-derived 4'-phosphopantetheine to a reactive serine residue in thiolation $(\mathrm{T})$ domains (also referred to as peptidyl carrier protein (PCP)) within the NRP synthetase (2). Initial strategies for assaying $4^{\prime}$-phosphopantetheinylation involved the use of $\left[{ }^{3} \mathrm{H}\right]$-pantetheine $\mathrm{CoA}$ and liquid scintillation counting (3), HPLC separation, and analysis of purified proteins (4). More recently, the application of protein mass spectrometry for the determination of apoenzyme 4'-phosphopantetheinylation has been reported $(2,5)$. These conventional methods for assaying PPTase activity, however, can be costly and cumbersome and significantly limit high-throughput operations (6).

An elegant method of covalently labeling T/PCP domains of NRP synthetases, using biotinylated or fluorescently labeled CoA, and a recombinant Bacillus subtilis encoded PPTase, Sfp, in PPTase-mediated reactions has been described (6). These authors used Sfp to catalyze modification of carrier proteins with a single fluorescent or affinity reporter, providing a sensitive means of protein visualization, Western blot identification, and affinity purification. This labeling technique also has utility in the identification of carrier protein domains from lysates of native cultures, as a proportion of carrier proteins in the lysate may be present in an unmodified inactive state. Application of the technique to the 6-deoxyerythronolide B synthase (DEBS)

* Corresponding author. Professor Sean Doyle, National Institute for Cellular Biotechnology, Department of Biology, National University of Ireland Maynooth, Co. Kildare, Ireland. Tel: +353-1-7083858, Fax: +353-1-7083845, E-mail: sean.doyle@nuim.ie. pathway from Saccharapolyspora erythraea resulted in the identification of a $150 \mathrm{kDa}$ protein indicative of native DEBS (6).

The ability of PPTases to post-translationally modify carrier proteins using low molecular mass chemical labels represents a novel and efficient tool for protein labeling and has significant implications in biomolecular research. This approach has been adapted to fluorescence imaging of cellular events involving transferrin-mediated iron uptake (7) where the transferrin receptor 1 (TfR1) was fused to a PCP, and the resultant TfR1PCP fusion specifically labeled with a fluorophore via the action of Sfp. In an independent study, an 11-residue peptide, DSLEFIASKLA, predicted to be a suitable target for modification by the B. subtilis Sfp was fused to the C- and N-termini of target protein and subsequently labeled with a biotin tag by the PPTase (8). The majority of reporter labeling of carrier proteins by promiscuous PPTases have been limited to in vitro and cell surface protein labeling $(9-11)$. A chemoenzymatic route to protein modification in vivo using a fluorescent marker has also been reported (12). This mechanism centered on the ability of native enzymes present in E. coli, CoAA, and CoAD and CoAE to sequentially modify a fluorescent pantetheine analogue to result in a fluorescently labeled CoA analogue. Coexpression of the carrier protein VibB and the PPTase Sfp in the presence of the fluorescent pantetheine analogue resulted in the fluorescent modification of the VibB carrier protein in vivo.

The PPTase-mediated modification of bacterial pyochelin NRP synthetase carrier proteins PchE and PchF using fluorescein (Fl)-CoA analogues has also been reported (13). These in vitro 4'-phosphopantetheinylation assays used $2 \mu \mathrm{M} \mathrm{B}$. subtilis $\mathrm{Sfp}$, $300 \mu \mathrm{M}$ Fl-CoA, and PchE/ PchF carrier proteins at concentrations of 10 and $21 \mu \mathrm{M}$, respectively. The detection of the modified carrier proteins in this study was enabled by Fourier transform mass spectrometry whereby mass shifts were observed for reporter labeled peptides.

In vitro 4 '-phosphopantetheinylation assays have been used to investigate the effect of inhibitors on PPTase activity (14). 


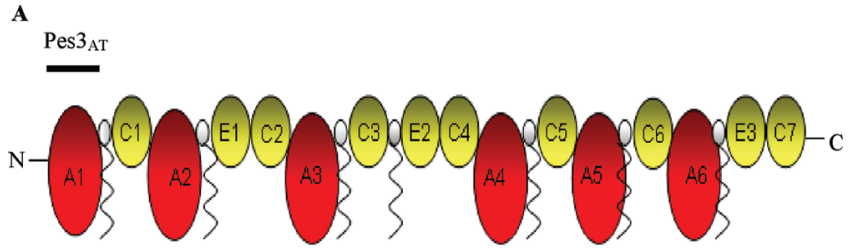

B

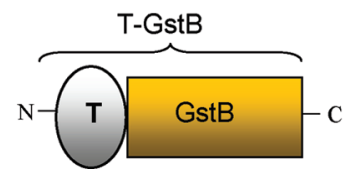

Figure 1. Diagrammatic representation of (A) Pes3 domain architecture, and (B) thiolation (T)-GstB fusion protein. The first adenylation domain and thiolation domain from module 1 of Pes 3 (Pes $3_{\mathrm{AT}}$ ) were selected for recombinant protein production. Wavy lines shown in A indicate covalently tethered phosphopantetheine moieties to T domains (shaded). The T-GstB fusion protein is also illustrated showing the Pes 3 thiolation domain (T) fused to the GstB protein. The N- and C-termini of both proteins are indicated.

Here, the efficacy of novel anthranilic acid inhibitors of the $B$. subtilis acyl carrier protein synthase $(\mathrm{AcpS})$, which catalyzes the transfer of $4^{\prime}$-phosphopantetheinyl group from CoA onto a conserved serine residue present on an E. coli acyl carrier protein $(\mathrm{ACP})$, was assessed and found to exhibit $\mathrm{IC}_{50}(\mu \mathrm{M})$ values of $0.82-32.3$. The effect of these inhibitors was determined in a solution phase assay format, which involved incubation of the AcpS (a PPTase) in the presence of a GST-linked ACP carrier protein and a biotin-CoA reporter analogue at room temperature. Detection of the biotin-labeled ACP was achieved by an overnight incubation with streptavidin-allophycocyanin conjugate followed by time-resolved fluorescence detection.

A PPTase from Aspergillus fumigatus has recently been expressed in, and purified from, recombinant baculovirus infected Spodoptera frugiperda $a_{9}\left(\mathrm{Sf}_{9}\right)$ insect cell supernatants. Subsequent mass spectrometric detection of a 4 '-phosphopantetheinylated peptide confirmed that this secreted PPTase posttranslationally modified a recombinant NRP synthetase T domain from A. fumigatus Pes1 in the presence of CoA (2). To date, the compatibility of this fungal PPTase has not been demonstrated with modified CoA derivatives; moreover, limited amounts of the secreted PPTase has hindered complete enzyme characterization, and the assay systems for detection of $4^{\prime}$ phosphopantetheinylation are cumbersome and time-consuming.

\section{EXPERIMENTAL METHODS}

Bioinformatic Analysis. Preliminary sequence data were obtained from The Institute for Genomic Research Website at http://www.tigr.org. The unannotated genome of Aspergillus fumigatus was initially investigated to identify open reading frames corresponding to novel NRP synthetases. One open reading frame, which encoded a putative NRP, was identified and was subsequently termed pes3 (Figure 1).

Fungal DNA Isolation and PCR Amplification. A. fumigatus strain ATCC 26933 was grown $(250 \mathrm{~mL}$ cultures) at 37 ${ }^{\circ} \mathrm{C}$ in minimal essential medium (MEM) $(5 \%(\mathrm{v} / \mathrm{v})$ containing fetal calf serum (FCS)) for 2 days. Genomic DNA was isolated by crushing fungal mycelia in liquid $\mathrm{N}_{2}$ followed by phenol/ chloroform extraction, washing with $70 \%(\mathrm{v} / \mathrm{v})$ ethanol and final DNA resuspension in $10 \mathrm{mM}$ Tris- $\mathrm{HCl}, 1 \mathrm{mM}$ EDTA $\mathrm{pH} 8.0$ $(200 \mu \mathrm{L})$. PCR was carried out using AccuTaq LA polymerase (Sigma) using a total of $5 \mathrm{ng}$ of genomic DNA per PCR reaction. PCR reactions also included $10 \times$ AccuTaq reaction buffer, 0.25 $\mu \mathrm{M}$ of each dNTP, $1.0 \mu \mathrm{M}$ forward and reverse primer (Table 1) in a total volume of $20 \mu \mathrm{L}$. PCR reactions comprised an
Table 1. Oligonucleotide Primers Designed for Directional Cloning of $p e s 3_{A T}$ and $T / P C P$ Region Sequences into the pProEx-GstB Expression Vector

\begin{tabular}{cccc}
\hline gene & $(\mathrm{F} / \mathrm{R})$ & primer sequences $\left(5^{\prime}-3^{\prime}\right)$ & $\begin{array}{c}\text { amplicon } \\
(\mathrm{bp})\end{array}$ \\
\hline pes $_{A T}$ & $\mathrm{~F}$ & GAGACTCGAGACATACGCCGAACTGGAA & 1800 \\
pes $3_{A T}$ & $\mathrm{R}$ & GAGAAAGCTTAGTGATCGAGGAACGCAA & \\
$T / P C P$ & $\mathrm{~F}$ & GAGAGGATCCCATGGAACGCCGGTTGCGAG & 196 \\
$T / P C P$ & $\mathrm{R}$ & GAGAGAATTCTGCGAGCTCTGTGATGGA &
\end{tabular}

initial step of $60 \mathrm{~s}$ denaturation at $95^{\circ} \mathrm{C}$, followed by 30 cycles consisting of $60 \mathrm{~s}$ at $95{ }^{\circ} \mathrm{C}, 30 \mathrm{~s}$ at $55^{\circ} \mathrm{C}, 90 \mathrm{~s}$ at $72{ }^{\circ} \mathrm{C}$, and finally $360 \mathrm{~s}$ at $72{ }^{\circ} \mathrm{C}$. Amplicons were analyzed by agarose gel electrophoresis and visualized using an Eagle-Eye II digital still video system (Stratagene, CA, USA). DNA sequence analysis was carried out on a commercial basis by MWG Biotech (Germany).

Cloning and Expression of the Nonribosomal Peptide Synthetase Gene Fragment, pes $3_{A T}$. The pes $3_{A T}$ amplicon, which is derived from the $5^{\prime}$ end of the entire pes 3 gene (Figure 1), was initially cloned into the TOPO cloning vector and subsequently cloned into pProEx expression vectors (Invitrogen) according to the manufacturer's instructions. pProEx:pes $3_{A T}$, the expression vector containing the region encoding the initial AT didomain of pes3 (A. fumigatus pes $3_{A T}$ ) (Figure 1), was transformed into $E$. coli according to the manufacturer's guidelines (Invitrogen). Protein expression was induced by the addition of isopropyl $\beta$-D-1-thiogalactopyranoside (IPTG; 0.6 $\mathrm{mM}$ final concentration) and monitored by SDS-PAGE, Western blot analysis using monoclonal antibody reactivity against a $\mathrm{His}_{6}$ fusion peptide, and MALDI-ToF mass spectrometry (15).

Recombinant Pes3 $3_{\mathrm{AT}}$ Purification and Refolding. Recombinant Pes $3_{\mathrm{AT}}$ was purified under denaturing conditions using Ni-NTA metal-chelate affinity chromatography in the presence of $6 \mathrm{M}$ guanidine- $\mathrm{HCl}$. Purified recombinant Pes $3_{\mathrm{AT}}(250 \mu \mathrm{g} /$ $\mathrm{mL}$ ) in $50 \mathrm{mM}$ sodium carbonate $\mathrm{pH} 9.4$ containing $6 \mathrm{M}$ guanidine-HCL was serially dialyzed into $50 \mathrm{mM}$ sodium carbonate $\mathrm{pH} 9.4$ containing $8 \mathrm{M}$ urea, then $4 \mathrm{M}$ urea, followed by dialysis into $50 \mathrm{mM}$ sodium carbonate buffer $\mathrm{pH} 9.4$ to facilitate solubilization.

Generation of Recombinant Fusion Protein (T-GstB) Containing the Pes3 $3_{\mathrm{AT}}$ Derived Thiolation Domain. The region encoding the thiolation (PCP) domain from pes $3_{A T}$ was fused to A. fumigatus glutathione s-transferase B ( $g s t B(16)$ ) in order to assess the utility of the domain for non-native protein labeling (Figure 1). PCR cloning primers incorporated EcoRI and HindIII restriction sites to facilitate PCR amplification and directional subcloning of the T region (Table 1). This amplicon (196 bp) was subsequently digested with EcoRI and HindIII and ligated to the pProEx-gst $B$ expression vector (16), which had also been digested with EcoRI and HindIII. The expression vector containing T-GstB was then transformed into $E$. coli DH5 $\alpha$ according to refs 16 and 17. Protein expression was induced by the addition of IPTG (0.6 mM final concentration) and monitored by SDS-PAGE and Western blot analysis. Purification of the T-GstB fusion protein was carried out as previously described (2).

PPTase Extraction from Infected ( $\mathbf{S f}_{9}$ ) Insect Cells. $\mathrm{Sf}_{9}$ insect cells $\left(5 \times 10^{7}\right)$, previously infected with recombinant baculovirus encoding PPTase (2), were resuspended in Ppant buffer (5 mL; $75 \mathrm{mM}$ Tris-HCl, $5 \mathrm{mM}$ dithiothreitol (DTT), and $10 \mathrm{mM} \mathrm{MgCl}_{2} \mathrm{pH} \mathrm{8.0)}$ and sonicated (Bandelin Sonopuls, Progen Scientific Ltd., UK) for $3 \times 5 \mathrm{~s}$ at a maximum power for $5 \mathrm{~min}$ with $30 \mathrm{~s}$ second intervals on ice. The resultant cell lysates were centrifuged at $10000 \mathrm{~g}$ for $10 \mathrm{~min}$ at $4{ }^{\circ} \mathrm{C}$. The supernatants were removed and analyzed for the presence of PPTase by Western blot analysis. The concentration of protein present in the cell lysate supernatants was determined by 
Bradford analysis and the supernatants divided into $0.5 \mathrm{~mL}$ aliquots and stored at $-20{ }^{\circ} \mathrm{C}$ for further use.

For purification of intracellular PPTase, infected $\mathrm{Sf}_{9}$ insect cells $\left(5 \times 10^{7}\right)$ were resuspended in lysis buffer $(5 \mathrm{~mL} ; 50 \mathrm{mM}$ $\mathrm{NaH}_{2} \mathrm{PO}_{4}, 300 \mathrm{mM} \mathrm{NaCl}, 10 \mathrm{mM}$ imidazole $\mathrm{pH}$ 8.0) containing $0.05 \%(\mathrm{w} / \mathrm{v})$ sodium deoxycholate and sonicated (Bandelin Sonopuls, Progen Scientific Ltd., UK) for $3 \times 5$ s at a maximum power for $5 \mathrm{~min}$ with $30 \mathrm{~s}$ intervals on ice and the resultant lysates centrifuged at $10000 \mathrm{~g}$ for $10 \mathrm{~min}$ at $4{ }^{\circ} \mathrm{C}$. Purification proceeded under native conditions using Ni-NTA metal-chelate affinity chromatography. Optimal protein yields were obtained using an optimized batch purification approach which entailed the incubation of the PPTase lysate to the Ni-NTA resin for $2 \mathrm{~h}$ with gentle inversion at $4{ }^{\circ} \mathrm{C}$. Subsequently, the protein/ resin complex was packed into a column to facilitate washing and elution steps. Purified PPTase was eluted with $250 \mathrm{mM}$ imidazole and subsequently dialyzed into Ppant buffer.

Coenzyme A Analogue Synthesis and Solution Phase PPTase Activity Analysis. Coenzyme A (CoA) was covalently labeled through an available sulfhydral group by reaction with

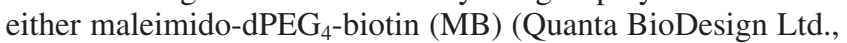
Ohio, USA) or 5'-iodoacetamidofluorescein (Sigma-Aldrich) according to ref 6 with modifications (Supporting Information). All reactions were allowed to proceed on ice for $30 \mathrm{~min}$, followed by $10 \mathrm{~min}$ incubation at room temperature, and terminated by addition of 1 M DTT $(1 \mu \mathrm{L})$. 4'-Phosphopantetheinylation reactions using PPTase and recombinant Pes $3_{\mathrm{AT}}$ were carried out as follows: Reaction mixtures for the in vitro $4^{\prime}$-phosphopantetheinylation assay contained Pes $3_{\mathrm{AT}}(4.4 \mu \mathrm{M})$, PPTase $(0.08 \mu \mathrm{M})$, biotin-CoA $(8.4 \mu \mathrm{M})$ in $75 \mathrm{mM}$ Tris-HCL, $5 \mathrm{mM}$ DTT, and $10 \mathrm{mM} \mathrm{MgCl}, \mathrm{pH} 8.0$ (final volume: 100 $\mu \mathrm{L})$. Reaction mixtures were incubated at $37^{\circ} \mathrm{C}$ for $1 \mathrm{~h}$. After incubation, reactions were terminated by the addition of $10 \%$ $(\mathrm{w} / \mathrm{v})$ trichloroacetic acid $(900 \mu \mathrm{L})$ and centrifuged at $10000 \mathrm{~g}$ for $10 \mathrm{~min}$. Pellets were resuspended in $1 \mathrm{M}$ Tris- $\mathrm{HCl} \mathrm{pH} 8.0$ and analyzed by SDS-PAGE and Western blot analysis, using direct probing with streptavidin-horseradish peroxidase (HRP) (1/500) and ECL chemiluminescent substrate (Pierce Biotechnology), to visualize biotinylated Pes $3_{\mathrm{AT}}$. Fluorescence detection was also undertaken by directly scanning SDS-PAGE gels, when fluorescein-CoA (Fl-CoA) (6) was employed instead of biotinCoA (6), using a Typhoon variable mode imager (GE Healthcare) at excitation and emission wavelength at 488 and $520 \mathrm{~nm}$, respectively. Scanned gels were subsequently stained with Coomassie Brilliant Blue R. Alternatively, reaction mixtures were directly added to Nunc Maxisorb microwells (1 h), washed using phosphate buffered saline $0.05 \%$ (w/v) Tween-20 (PBST), and fluorescence detected using a plate reader (Bio-Tech, Synergy HT) with excitation and emission values of 490 and $520 \mathrm{~nm}$, respectively.

Microwell Coating with Recombinant Pes3 $3_{\text {AT }}$, T-GstB, or GstB for Use in Solid Phase 4'-Phosphopantetheinylation Assays. Microtiter plates were coated with purified recombinant Pes $3_{\mathrm{AT}}(2 \mu \mathrm{g} / \mathrm{mL})$ diluted in $50 \mathrm{mM}$ sodium carbonate buffer $\mathrm{pH} 9.6$ containing $0.01 \%(\mathrm{w} / \mathrm{v})$ sodium dodecyl sulfate $\left(100 \mu \mathrm{L} /\right.$ well). Plates were incubated at $37{ }^{\circ} \mathrm{C}$ for $2 \mathrm{~h}$ and washed twice with PBST $(200 \mu \mathrm{L})$. Blocking solution $(1 \%$ $(\mathrm{w} / \mathrm{v})$ bovine serum albumin and $10 \%(\mathrm{w} / \mathrm{v})$ sucrose in $50 \mathrm{mM}$ sodium carbonate buffer $\mathrm{pH} 9.6 ; 200 \mu \mathrm{L} /$ well) was applied to the wells and stored at $4{ }^{\circ} \mathrm{C}$ overnight. Blocking solution was decanted from plates, and any residual solution was removed by tapping the plate upside down onto adsorbent paper and transferring the plate to a $37{ }^{\circ} \mathrm{C}$ incubator for $1 \mathrm{~h}$ prior to use. Microwells were also individually coated with the T-GstB and GstB, respectively ( $5 \mu \mathrm{g} / \mathrm{mL})$, for subsequent use in the solid phase $4^{\prime}$-phosphopantetheinylation assays. Microwell coating
Table 2. Reagent Preparation for Solid Phase 4'-Phosphopantetheinylation Assay ${ }^{a}$

\begin{tabular}{|c|c|c|c|c|c|}
\hline $\begin{array}{l}\text { reagent stock } \\
\text { solutions }\end{array}$ & $\begin{array}{l}\text { purified } \\
\text { PPTase }\end{array}$ & $\begin{array}{l}\text { PPTase crude } \\
\text { cell lysate }\end{array}$ & $\begin{array}{l}\text { control cell } \\
\text { lysate }\end{array}$ & $\begin{array}{l}\text { biotin CoA } \\
\text { control }\end{array}$ & $\begin{array}{l}\text { buffer } \\
\text { control }\end{array}$ \\
\hline $\begin{array}{l}\text { purified PPTase } \\
(0.5 \mu \mathrm{M})\end{array}$ & $95 \mu \mathrm{L}$ & - & - & - & - \\
\hline $\begin{array}{l}\text { PPTase lysate } \\
\text { (1.7 } \mathrm{mg} / \mathrm{mL} \text { total } \\
\text { cell protein })\end{array}$ & - & $30 \mu \mathrm{L}$ & - & - & - \\
\hline $\begin{array}{l}\text { control lysate } \\
(1.7 \mathrm{mg} / \mathrm{mL} \text { total } \\
\text { cell protein })\end{array}$ & - & - & $30 \mu \mathrm{L}$ & - & - \\
\hline biotin-CoA $(109 \mu \mathrm{m})$ & $5 \mu \mathrm{L}$ & $5 \mu \mathrm{L}$ & $5 \mu \mathrm{L}$ & $5 \mu \mathrm{L}$ & - \\
\hline Ppant buffer & - & $55 \mu \mathrm{L}$ & $55 \mu \mathrm{L}$ & $95 \mu \mathrm{L}$ & $100 \mu \mathrm{L}$ \\
\hline
\end{tabular}

${ }^{a}$ Final reagent concentrations: Biotin-CoA $(5.4 \mu \mathrm{M})$, PPTase purified from infected $\mathrm{Sf}_{9}$ cell supernatants $(0.48 \mu \mathrm{M})$, PPTase cell lysate obtained from infected $\mathrm{Sf}_{9}$ insect cells $(0.51 \mathrm{mg} / \mathrm{mL}$ total cell protein), and as a control, cell lysate obtained from un-infected $\mathrm{Sf}_{9}$ insect cells $(0.51 \mathrm{mg} / \mathrm{mL}$ total cell protein $)$.

Table 3. Reagent Preparation for Solid Phase

$4^{\prime}$-Phosphopantetheinylation Assay (B) ${ }^{a}$

\begin{tabular}{lccccc}
\hline reagents & $\begin{array}{c}\text { purified } \\
\text { PPTase }\end{array}$ & $\begin{array}{c}\text { PPTase crude } \\
\text { cell lysate }\end{array}$ & $\begin{array}{c}\text { control cell } \\
\text { lysate }\end{array}$ & $\begin{array}{c}\text { Fl-CoA } \\
\text { control }\end{array}$ & $\begin{array}{c}\text { buffer } \\
\text { control }\end{array}$ \\
\hline $\begin{array}{c}\text { purified PPTase } \\
(0.5 \mu \mathrm{M})\end{array}$ & $95 \mu \mathrm{L}$ & & & & \\
$\begin{array}{c}\text { PPTase lysate } \\
(1.7 \mathrm{mg} / \mathrm{mL} \text { total }\end{array}$ & - & $30 \mu \mathrm{L}$ & - & - & - \\
$\quad$ cell protein) & & & & & \\
$\begin{array}{c}\text { control lysate } \\
(1.7 \text { mg/mL total }\end{array}$ & - & - & $30 \mu \mathrm{L}$ & - & - \\
cell protein) & & & & & \\
Fl-CoA $(95 \mu \mathrm{M})$ & $5 \mu \mathrm{L}$ & $5 \mu \mathrm{L}$ & $5 \mu \mathrm{L}$ & $5 \mu \mathrm{L}$ & - \\
Ppant buffer & - & $60 \mu \mathrm{L}$ & $60 \mu \mathrm{L}$ & $90 \mu \mathrm{L}$ & $100 \mu \mathrm{L}$
\end{tabular}

${ }^{a}$ Final reagent concentrations; Fl-CoA $(3.6 \mu \mathrm{M})$, PPTase purified from infected $\mathrm{Sf}_{9}$ cell supernatants $(0.48 \mu \mathrm{M})$, PPTase cell lysate obtained from infected $\mathrm{Sf}_{9}$ insect cells $(0.51 \mathrm{mg} / \mathrm{mL}$ total cell protein $)$, and as a control, cell lysate obtained from un-infected $\mathrm{Sf}_{9}$ insect cells $(0.51 \mathrm{mg} / \mathrm{mL}$ total cell protein $)$.

of T-GstB and GstB and subsequent 4'-phosphopantetheinylation assays were carried out as described for Pes $3_{\mathrm{AT}}$.

Solid Phase 4'-Phosphopantetheinylation Using BiotinCoA. Reactants were prepared in triplicate in $1.5 \mathrm{~mL}$ microfuge tubes as outlined in Table 2 . Aliquots $(100 \mu \mathrm{L})$ of each sample were placed in wells of 96-well plates (Nunc Maxisorb) which had been previously coated with Pes $3_{\mathrm{AT}}(2 \mu \mathrm{g} / \mathrm{mL})$. Plates were incubated for $1 \mathrm{~h}$ at room temperature to facilitate enzymatic reaction. Plates were then washed twice with PBST. Streptavidin-HRP (1/2000 dilution; $100 \mu \mathrm{L} /$ well) was added and plates incubated at $37{ }^{\circ} \mathrm{C}$ for $1 \mathrm{~h}$. Plates were washed 4 times with PBST. Excess liquid was removed from the wells by tapping the plate out on adsorbent paper. Substrate $\left(3,3^{\prime}, 5,5^{\prime}-\right.$ tetramethylbenzidine; TMB; $100 \mu \mathrm{L} /$ well) was applied to the wells and left to develop for $10 \mathrm{~min}$ at room temperature. To terminate the reaction, $1 \mathrm{~N} \mathrm{H}_{2} \mathrm{SO}_{4}(100 \mu \mathrm{L})$ was added to the wells, and the absorbance values read at 450/630 nm using a plate reader (Bio-Tech, Synergy HT).

Solid Phase 4'-Phosphopantetheinylation Using Fl-CoA. Reactants were prepared in triplicate in $1.5 \mathrm{~mL}$ microfuge tubes as outlined in Table 3 . Aliquots $(100 \mu \mathrm{L})$ of each sample were placed in wells of black 96-well plates (Nunc Maxisorb) which had been previously coated with Pes $3_{\mathrm{AT}}(2 \mu \mathrm{g} / \mathrm{mL})$. Plates were incubated for $1 \mathrm{~h}$ at room temperature in the dark while the enzymatic reaction occurred. Plates were then washed twice with PBST and excess liquid removed by tapping the plates on adsorbent paper. Fluorescence was detected using a plate reader (Bio-Tech, Synergy HT) with excitation and emission values of 490 and $520 \mathrm{~nm}$, respectively.

PPTase Characterization Using Solid Phase 4'-Phosphopantetheinylation Assay. Temperature and $\mathrm{pH}$ optima, along with PPTase reaction time, were determined. In addition, the effect of protease inhibitors (phenylmethylsulfonyl fluoride; 


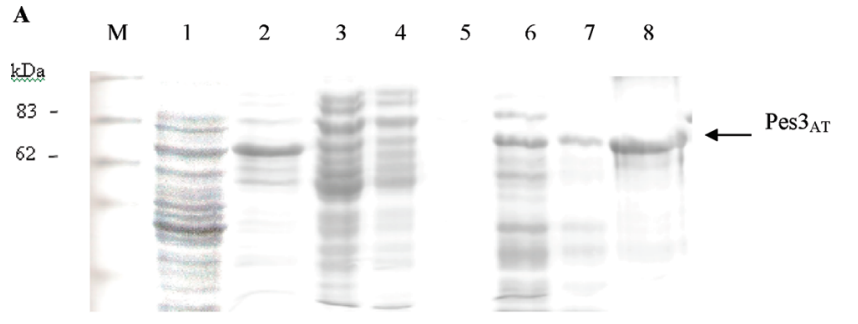

B

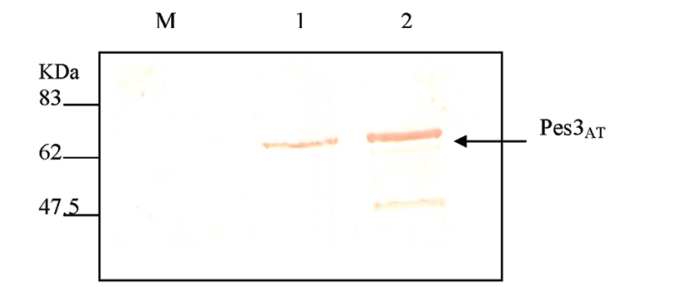

C

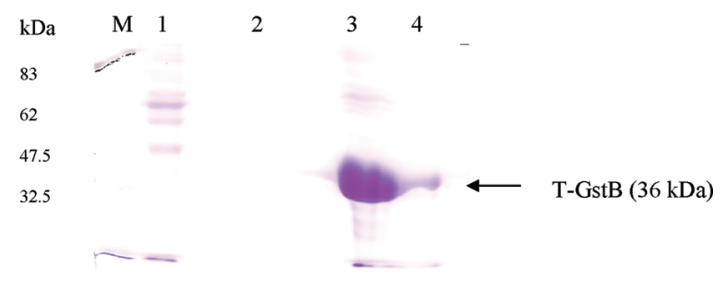

D

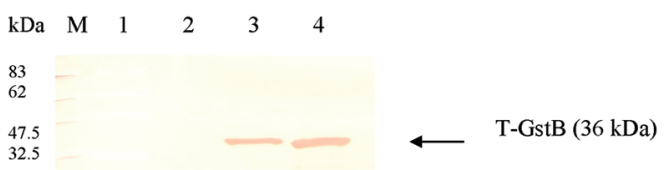

Figure 2. Purification of recombinant $\mathrm{Pes} 3_{\mathrm{AT}}$ and $\mathrm{T}-\mathrm{GstB}$ by differential extraction. (A) Coomassie stained SDS-PAGE gel of Pes $3_{\mathrm{AT}}$ fractions obtained from crude extraction method. Lane $\mathrm{M}$, molecular mass marker; lane 1, unpurified Pes $3_{\mathrm{AT}}$; lane 2, cell lysate; lanes 3-5: Triton $\mathrm{X}-100$ washes; lane 6, $2 \mathrm{M}$ urea wash; lane 7, $8 \mathrm{M}$ urea wash; lane 8, purified Pes $3_{\mathrm{AT}}$ in $6 \mathrm{M}$ guanidine- $\mathrm{HCl}$. (B) Western blot analysis of Pes $3_{\mathrm{AT}}$. Lane M, molecular mass marker; lane 1, unpurified Pes $3_{\mathrm{AT}}$; lane 2 , Pes $3_{\text {Ат }}$ purified by differential extraction method. Western blot analysis was carried out using 1/1000 dilution of anti-His ${ }_{6}$ monoclonal $^{2}$ antibody and 1/1000 dilution of anti-mouse IgG-HRP conjugate. (C) SDS-PAGE analysis of T-GstB fractions obtained from crude extraction method. Lane M, molecular mass marker; lane 1, unpurified T-GstB lysate; lane 2, wash fraction; lane 3,8 M urea wash (20 $\mu \mathrm{g})$; lane 4, 8 M urea wash $(2 \mu \mathrm{g})$. (D) Western blot analysis of purified T-GstB. Lane M, molecular mass marker; lane 1, T-GstB lysate; lane 2, wash fraction; lanes 3 and $4,8 \mathrm{M}$ urea wash ( 0.5 and $1 \mu \mathrm{g} /$ track, respectively) T-GstB.

PMSF) inclusion on PPTase cell lysate stability was investigated. Student's $t$ test was used to assess the statistical significance of relevant results. Absorbance values for control lysate (lacking PPTase) were subtracted from PPTase lysates for calculation of relative PPTase activity (\%). The mean absorbance value for purified PPTase was set at $100 \%$ with all other values (PPTase lysate and biotin-CoA controls) expressed as a percentage of this.

\section{RESULTS}

Recombinant Protein Expression, Purification, and Solubilization. Pes $3_{\mathrm{AT}}$ was found to be highly insoluble under nondenaturing conditions (data not shown) and was solubilized by addition of $6 \mathrm{M}$ guanidine $-\mathrm{HCl}$ containing $1 \mathrm{mM}$ DTT to a final concentration of $30 \mathrm{mg} / \mathrm{mL}$ or $5 \mathrm{mg} / \mathrm{g}$ cells. SDS-PAGE analysis and Western blot analysis confirmed the required purity of Pes $3_{\mathrm{AT}}$ (Figure 2). The $72 \mathrm{kDa}$ Pes $3_{\mathrm{AT}}$ band observed on the Coomassie stained gel was excised and subjected to MALDIToF mass spectrometry. Resultant tryptic digest peptide monoiso-
Table 4. Peptides Identified Following Trypsin Digestion of Recombinant Pes3 $3_{\mathrm{AT}}$ and MALDI-ToF Mass Spectrometry Analysis ${ }^{a}$

\begin{tabular}{ll}
\hline$m / z(\mathrm{Da})$ & \multicolumn{1}{c}{ identified peptides } \\
\hline 900.39 & R Y A D W M A K Y L M V K R \\
1656.85 & K K S V W T M V A M L A I M K \\
1590.88 & K R I L D D T E A P L V I V H R \\
1523.84 & K G I V V P H R I A T S M R \\
1930.95 & R W N D L A G A M R L G V N W A K \\
1288.737 & R L L H P Q V P S L R \\
1674.8 & R Q V G G T L H V V D A G N H R R \\
1273.61 & H R D D G V Y Y L L G R \\
1531.66 & K V A E H T D T S AD N E R \\
${ }^{a}$ The peptides identified represent 20\% coverage of the Pes $3_{\mathrm{AT}}$ and \\
confirm the identity of the protein.
\end{tabular}

$\mathbf{A}$

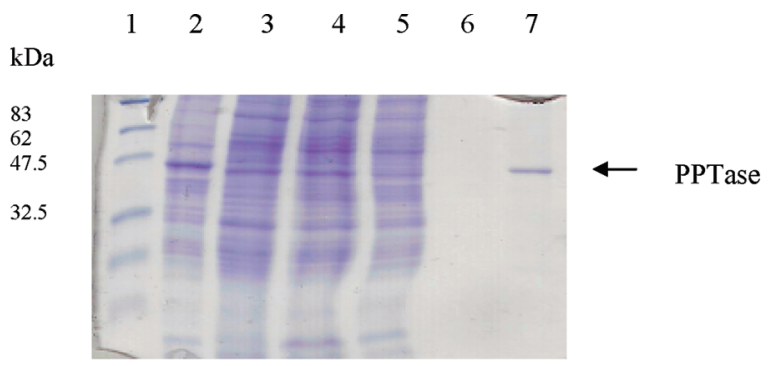

B

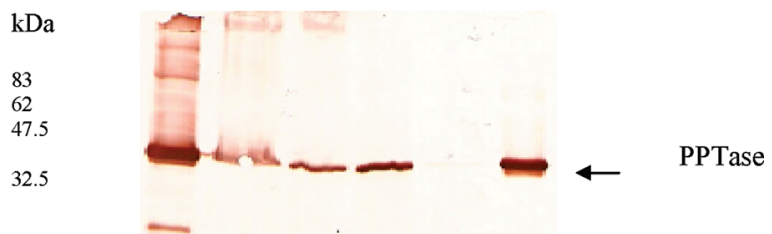

Figure 3. Purification of intracellular PPTase from $\mathrm{Sf}_{9}$ cell lysate. (A) SDS-PAGE and (B) Western blot analysis of PPTase purification using anti-His ${ }_{6}$ monoclonal antibody and 1/1000 dilution of anti-mouse IgGHRP conjugate. Lane 1, molecular mass markers; lane 2, control PPTase cell lysate; lane 3, PPTase cell lysate 1; lanes 4-6, unbound; lane 7: Ni-NTA affinity column eluate containing purified PPTase.

topic $\mathrm{m} / \mathrm{z}$ values (Table 4), compared to those of an in silico digest of Pes $3_{\mathrm{AT}}$, represented $20 \%$ sequence coverage thereby providing conclusive confirmation of Pes $3_{\mathrm{AT}}$ identity. Pes $3_{\mathrm{AT}}$ was solubilized under nondenaturing conditions by dilution into Ppant buffer containing $8 \mathrm{M}$ urea $(4 \mathrm{~mL})$ at $0.5 \mathrm{mg} / \mathrm{mL}$ Pes $3_{\mathrm{AT}}$ followed by serial dialysis into Ppant buffer (final concentration: $0.41 \mathrm{mg} / \mathrm{mL}(5.75 \mu \mathrm{M}))$. This solubilized Pes $3_{\mathrm{AT}}$ preparation was aliquoted and stored at $-20^{\circ} \mathrm{C}$ for subsequent use. The 36 $\mathrm{kDa}$ T-GstB fusion protein was purified from $E$. coli cell lysates resulting in a T-GstB yield of $13 \mathrm{mg} / \mathrm{mL}$ or $5 \mathrm{mg} / \mathrm{g}$ cells (Figure 2).

Following infection with recombinant baculovirus encoding A. fumigatus PPTase, Spodoptera frugiperda insect cell lysates were prepared by sonication in the presence of $0.05 \%(\mathrm{w} / \mathrm{v})$ sodium deoxycholate in Ppant diluent. Purified PPTase was obtained by incubation with Ni-NTA affinity resin for $2 \mathrm{~h}$ followed by elution with $250 \mathrm{mM}$ imidazole and dialysis into Ppant diluent (yield: $0.33 \mathrm{mg} / 10^{8}$ cells) (Figure 3).

Labeled CoA Conjugate Synthesis. Biotin-CoA conjugates were prepared by reacting $\mathrm{MB}$ with $\mathrm{CoA}$ to form a stable thioether-mediated conjugate for subsequent assay development. Prior to addition of free DTT to scavange any unreacted MB, a new method was deployed to determine the efficiency of biotin-CoA conjugate formation, which involved determination of residual CoA using aldrithiol-4 (4,4'-dithiodipyridine) reagent (Supplementary information). This analysis confirmed ef- 
A

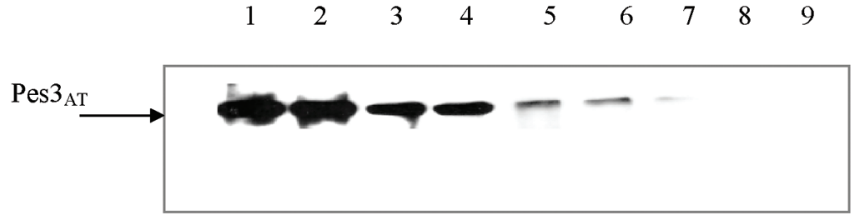

B

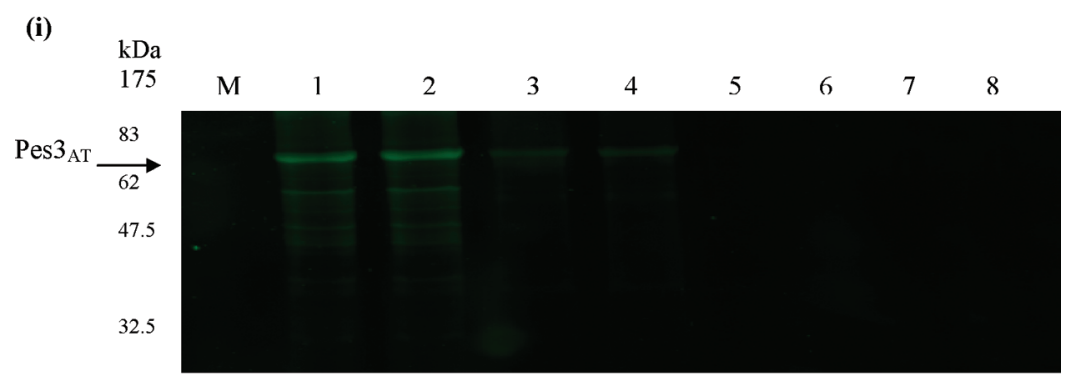

(ii)

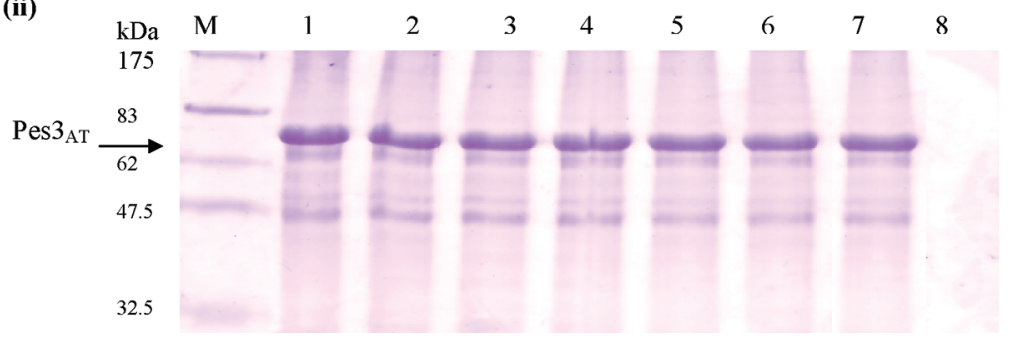

Figure 4. Chemoenzymatic labeling of Pes $3_{\mathrm{AT}}$. (A) Western blot showing $4^{\prime}$-phosphopantetheinylation of Pes $3_{\mathrm{AT}}$ using a range of PPTase-containing Sf9 cell lysates. Final concentrations of Pes $3_{\mathrm{AT}}(4.4 \mu \mathrm{M})$ and biotin CoA $(8.4 \mu \mathrm{M})$ were used. Western blots were probed with streptavidin- HRP and developed with ECL substrate. Lanes $1-7,1.7-0.003 \mathrm{mg} / \mathrm{mL}$, total cell protein; lane 8, Pes $3_{\mathrm{AT}}$ negative control; lane 9, Cell lysate negative control. Results shown are representative of duplicate analysis. (B) SDS-PAGE analysis of $4{ }^{\prime}$-phosphopantetheinylation of Pes $3_{\mathrm{AT}}$ by PPTase using fluorescein-CoA. (i) Fluorescent analysis was carried out on the Typhoon scanner (Amersham). Lane M, protein marker; lanes 1 and 2, PPTasecontaining cell lysate; lanes 3 and 4, purified PPTase $(0.08 \mu \mathrm{M})$; lanes 5 and 6, PPTase negative control; lane 7, Fl-CoA negative control; lane 8, Pes $3_{\mathrm{AT}}$ negative control. (ii) Coomassie staining of the above SDS-PAGE gel showing identical Pes $3_{\mathrm{AT}}$ loading (lanes 1-7).

fectively $90 \%+$ efficiency of biotin-CoA conjugate synthesis and extends the utility of aldrithiol-4 and other reagents used for thiol group determination (18). Previously, identical biotinCoA analogues were synthesized, the unincorporated biotin reporter extracted via the use of scavenger resins, and the resultant biotin-CoA reporter subsequently used for the highsensitivity detection (100 pg) of the biotin labeled recombinant VibB carrier protein domain (6). However, we observed minimal background protein modification once DTT was added to biotinCoA conjugates, which implies that removal of unreacted $\mathrm{MB}$ may not always be necessary. A fluorescently linked CoA analogue was also synthesized using $5^{\prime}$-iodoacetamidofluorescein (5'-IAF), which alkylates the sulfhydryl group of CoA. Fluorescent detection offers the potential advantage of direct analysis of labeled proteins without the need for enzyme conjugates and chemiluminescent substrates (19). The production of fluorescein-CoA was confirmed by TLC analysis; however, evidence of unreacted $5^{\prime}$-IAF in the fluorescein-CoA sample was also observed (data not shown). As with biotinCoA conjugates, it was found that subsequent addition of DTT eliminated nonspecific fluorescent labeling of target proteins. In addition, RP-HPLC analysis was also used to detect the production of fluorescein-CoA conjugates with the appearance of a new peak with a lower retention time of $17.0 \mathrm{~min}$ for the fluorescein-CoA test specimens which is likely due to the higher polarity of $\mathrm{Fl}-\mathrm{CoA}$ molecule compared to $5^{\prime}$-IAF (data not shown).
4'-Phosphopantetheinylation of Pes $3_{\mathrm{AT}}$ with Biotin- and Fluorescein-CoA is Mediated by PPTase. Pes $3_{\mathrm{AT}}$ was subject to specific $4^{\prime}$-phosphopantetheinylation by PPTase present in insect cell lysates (Figure 4a). Here, modification of the Pes $3_{\mathrm{AT}}$ $(4.4 \mu \mathrm{M})$ was clearly detectable using PPTase-containing insect cell lysates $(17-1700 \mu \mathrm{g} / \mathrm{mL}$ total protein), with a weak signal, corresponding to specific $4^{\prime}$-phosphopantetheinylation, at $3 \mu \mathrm{g}$ / $\mathrm{mL}$ total cell protein. No $4^{\prime}$-phosphopantetheinylation was detectable in the presence of control insect cell lysate, thereby providing confirmation that modification of Pes $3_{\mathrm{AT}}$ with biotinCoA was mediated specifically by PPTase and not as a result of direct nonspecific labeling of $\mathrm{Pes} 3_{\mathrm{AT}}$ with residual $\mathrm{MB}$. Omission of Pes $3_{\mathrm{AT}}$ from the reaction likewise produced a negative result, which confirmed that proteins in the insect cell lysate were not labeled nonspecifically with biotin-CoA (Figure 4a). Replacement of biotin-CoA with fluorescein-CoA as the PPTase substrate also facilitated post-translational modification of Pes $3_{\mathrm{AT}}$ (Figure $\left.4 \mathrm{~b}\right)$. Here, Pes3 $3_{\mathrm{AT}}(4.44 \mu \mathrm{M})$ was labeled using both purified PPTase $(0.08 \mu \mathrm{M})$ and PPTase present in insect cell lysate $\left(34 \mu \mathrm{g} / \mathrm{mL}\right.$ total cell protein). No $4^{\prime}$-phosphopantetheinylation was detectable in the absence of either PPTase or Pes $3_{\mathrm{AT}}$. Overall, these observations confirm that the Pes $3_{\mathrm{AT}}$ thiolation domain can be post-translationally modified by PPTase with either biotinylated or fluorescently labeled CoA.

High-Throughput Detection of 4'-Phosphopantetheinylation. Reaction mixtures containing combinations of purified PPTase, Pes $3_{\mathrm{AT}}$, and fluorescein-CoA were incubated in solution for $1 \mathrm{~h}$ and subsequently transferred to black microtiter plates, 


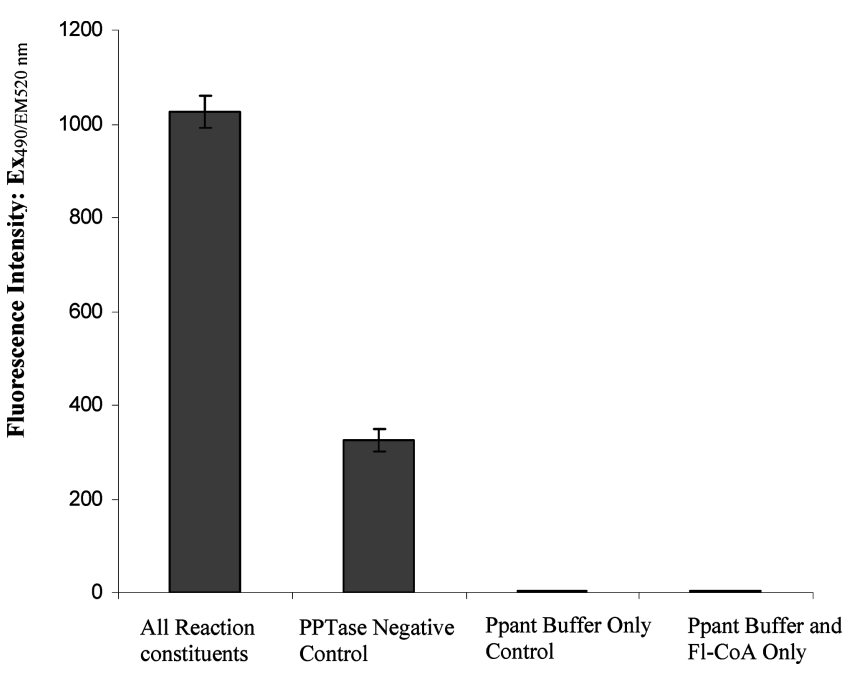

Figure 5. Solid phase $4^{\prime}$-phosphopantetheinylation assay using Fl-CoA. After solution phase incubation, $4^{\prime}$-phosphopantetheinylation reactions (and appropriate controls) were coated on black microtiter plates and subsequently analyzed by fluorescence with excitation and emission at 490 and $520 \mathrm{~nm}$, respectively. Results given represent the mean $( \pm \mathrm{SE})$ of the experiment performed in triplicate. All reaction constituents: Pes $3_{\mathrm{AT}}$; PPTase; Fl-CoA. PPTase negative control: PPTase absent from reactions. Ppant buffer control: Ppant buffer only. Ppant buffer and fluorescein-CoA (Fl-CoA) only: Pes $3_{\mathrm{AT}}$ and PPTase absent from reactions.

incubated for a further $1 \mathrm{~h}$, followed by washing with PBST $(2 \times)$ to remove unbound fluorescein-CoA. Fluorescent analysis at $490 / 520 \mathrm{~nm}$ (ex/em) (Figure 5) indicated that fluorescently labeled Pes $3_{\mathrm{AT}}$ had bound to the plate and was detectable by fluorescence analysis. Fluorescence labeling was predominantly mediated by PPTase modification; however, nonspecific labeling was also evident (up to 25\%) in the absence of PPTase. No fluorescence was detectable in the absence of Pes $3_{\mathrm{AT}}$.

For technical reasons, direct detection of biotinylated Pes $3_{\mathrm{AT}}$ on microwells was not possible as described for fluorescent Pes $3_{\text {AT }}$ above (data not shown). However, 4'-phosphopantetheinylation was possible using microwells precoated with Pes $3_{\mathrm{AT}}$ (4.4 pmol), and stabilized by BSA addition (Figure 6a). To ensure that biotin labeling of the bound $\operatorname{Pes} 3_{\mathrm{AT}}$ protein was the result of PPTase activity and not due to the presence of insect cell proteins present in the crude cell lysate, control reactions were included whereby uninfected insect cell lysates (at identical total protein concentration) were incubated in the Pes $3_{\mathrm{AT}}$ coated microwells in the presence of biotin-CoA, and resultant absorbance values compared to those obtained from incubation with PPTase insect cell lysate. Background activity was apparent in uninfected cell lysate controls compared to the biotin-CoA and Ppant buffer controls, but these absorbance values were only $16-25 \%$ of those obtained for the wells incubated with PPTase insect cell lysate (mean $A_{450 / 630 \mathrm{~nm}}: 1.7$ ), thereby confirming that labeling of Pes $3_{\mathrm{AT}}$ was due to PPTase present in the insect cell lysate. Consequently, PPTase cell lysate was used for subsequent analysis of PPTase activity using this assay format (Figure 6b). Control insect cell lysate (uninfected cells) was also included in subsequent analysis, and absorbance values obtained for these samples subtracted from the PPTase cell lysate specimens to correct for any nonspecific labeling that may be a result of native insect cell proteins. PPTase-mediated fluorescein-CoA modification of immobilized Pes $3_{\mathrm{AT}}$ has also been demonstrated (Figure $6 \mathrm{c}$ ). Here, nonspecific modification (approximately $25 \%$ of the PPTase reaction) was also evident.

Purified PPTase from insect cells lysates also functions in the solid phase 4'-phosphopantetheinylation reaction (Figure 6d). No significant difference was observed between purified PPTase and PPTase cell lysate (at an equivalent dilution; $P=0.56$ ), whereas significantly greater $4^{\prime}$-phosphopantetheinylaiton activity was evident compared to biotin-CoA only negative control $(P=0.00036)$.

Fungal Thiolation Domain Facilitates Labeling of NonNative Substrate Proteins. T-GstB was post-translationally modified by $4^{\prime}$-phosphopantetheinylation with biotinylated $4^{\prime}$ phosphopantetheine when immobilized in microwells (Figure 7). Moreover, background signal arising from GstB negative control was less than $5 \%$ of overall T-GstB signal, demonstrating conclusively that the discrete thiolation domain of T-GstB was specifically modified by PPTase activity, even when fused to a non-native protein (i.e., GstB).

Characterization of PPTase Activity. Following the establishment of the in vitro $4^{\prime}$-phosphopantetheinylation assay in a solid phase (96 well plate) format using biotin-CoA and PPTase insect cell lysates, temperature, $\mathrm{pH}$ optima, and reaction timecourse were investigated. Analysis of these data revealed that optimal PPTase activity was evident at $24^{\circ} \mathrm{C}$, with reduced $4^{\prime}$-phosphopantetheinylation observed at 4,37 , and $50{ }^{\circ} \mathrm{C}$ (Figure 8a). A statistically significant higher PPTase activity was observed when protease inhibitors were included in the insect cell lysates. This result implies that, in the absence of protease inhibitors, proteases present in the crude insect cell lysate may degrade PPTase and therefore lower the extent of post-translational modification (Figure 8a). The overall affect of $\mathrm{pH}$ on PPTase activity is shown in Figure $8 \mathrm{~b}$ whereby background absorbance values obtained from the insect cell lysate control samples were subtracted from the absorbance values obtained from PPTase lysate reactions. From this analysis, it is clear that $\mathrm{pH}$ has an effect on the activity of PPTase with optimal $4^{\prime}$-phosphopantetheinylation occurring at $\mathrm{pH}$ 8.0. 4'-Phosphopantetheinylation is $75 \%$ complete within $1 \mathrm{~h}$, and complete protein labeling is achieved after $3 \mathrm{~h}$ reaction (Figure 8c).

\section{DISCUSSION}

Despite recent advances in PPTase-mediated labeling of T/PCP or ACP domains of prokaryotic origin, via biotinylated or fluorescently modified CoA analogues, minimal information on this approach for eukaryotic (fungal) T domain modification is available. Moreover, facile determination of PPTase activity has remained a challenge. Here, data are presented which confirm that $\mathrm{T}$ domains of fungal origin can be post-translationally modified, both in solution and when immobilized on a solid surface, using a combination of modified CoA analogues and a functional PPTase. We also demonstrate that T domains can be transferred to a non-native protein (GstB) and that this fusion protein (T-GstB) is also a substrate for PPTase-mediated modification. Finally, it appears that the solid phase assay format presents a new strategy for determination of PPTase activity which is faster than current methods and is compatible with high-throughput functionality.

The gene encoding Pes3 represents the largest NRPS open reading frame in the A. fumigatus genome. Here, we have expressed the first AT didomain of Pes3 and a T-GstB fusion protein, in $E$. coli at high yields ( $5 \mathrm{mg} / \mathrm{g}$ cells). We have previously cloned and expressed recombinant PPTase in the baculovirus expression system, purified from PBS washes of intact cells by subsequent Ni-NTA chromatography, and shown it to be capable of transferring the Ppant group from CoA to the $\mathrm{T}$ domain derived from a distinct $A$. fumigatus NRPS (pes1) (2). However, in the present work we utilize PPTase, of intracellular origin, which was extracted in high yields (3.33 $\mathrm{mg} / 10^{9}$ cells) and purified by Ni-NTA affinity chromatography. Interestingly, PPTase activity was detectable in crude cell lysates, indicating that enzyme purification is not always essential. 

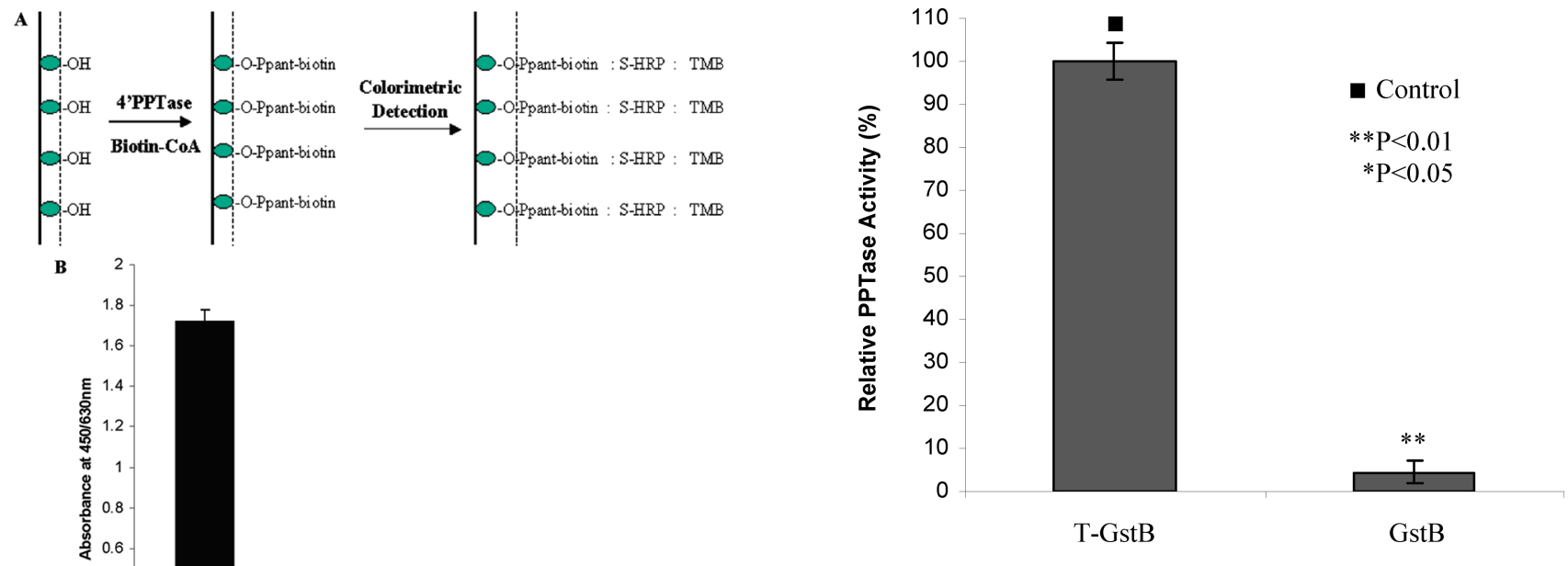

Figure 7. Solid phase 4'-phosphopantetheinylation of T-GstB. Net posttranslational modification activity in PPTase cell lysate, toward for T-GstB and GstB, respectively, was calculated by subtracting background signals in control insect cell lysate. Results given represent the mean $( \pm \mathrm{SE})$ of three individual experiments. Students $t$ test was used to calculate $P$-values for the difference between the T-GstB and the GstB $(P=0.0003)$.

To confirm reagent functionality, recombinant Pes $3_{\mathrm{AT}}$ was subjected to solution phase biotin- and fluorescein-CoA labeling, respectively, in the presence and absence of PPTase followed by chemiluminescent or direct fluorescence detection (Figure 4). Significantly, Pes $3_{\mathrm{AT}}(4.4 \mu \mathrm{M})$ labeling was observed in all cases in the presence of either purified PPTase or insect cell lysates, which contained impure, but active, preparations of the enzyme. To our knowledge, this is the first demonstration that fungal $\mathrm{T}$ domains can be chemoenzymatically labeled with CoA analogues, that crude PPTase preparations can be used to effect in vitro $4^{\prime}$-phosphopantetheinylation, and also that the enzyme produced within recombinant baculovirus-infected insect cells is active. Detection of fluorescein-labeled Pes3 $3_{\mathrm{AT}}(4.4 \mu \mathrm{M})$ was achieved using $7.3 \mu \mathrm{M}$ fluorescein-CoA and using either $0.08 \mu \mathrm{M}$ purified PPTase and crude PPTase cell lysate at a concentration of $0.034 \mathrm{mg} / \mathrm{mL}$ (estimated to contain $0.92 \mu \mathrm{M}$ PPTase). Thus, the molar ratios of purified PPTase, carrier protein, and fluoresceinCoA used were approximately 1:55:90. The PPTase mediated modification of the Pyochelin NRP synthetase carrier proteins PchE and PchF using similar fluorescein-CoA analogues has been reported (13). The in vitro $4^{\prime}$ phosphopantetheinylation assays used in that study, however, used $2 \mu \mathrm{M} \mathrm{B}$. subtilis $\mathrm{Sfp}$, $300 \mu \mathrm{M}$ fluorescein-CoA, and PchE/PchF carrier proteins at concentrations of 10 and $21 \mu \mathrm{M}$, respectively. The molar ratios of PPTase, carrier protein, and fluorescein-CoA in the present study were 1:5-10:150, respectively, similar to fluoresceinCoA-PPTase assay described herein; however, the assay of ref 13 required approximately 5 -fold more carrier protein and 25 times more PPTase (Sfp), respectively.

In order to eliminate the time-consuming electrophoretic step 6. (A) Diagrammatic representation of solid phase 4-phosphopantetheinylation. Immobilized thiolation domains (e.g., in Pes $3_{\mathrm{AT}}$ ) (green circles) are stabilized by the addition of BSA (dashed line). The reactive serine residue $(-\mathrm{OH})$ on the thiolation domain can then be modified with biotin-CoA in the presence of PPTase. PPTase activity is then indirectly detected by addition of streptavidin-HRP conjugate and TMB substrate. Fluorescein-CoA (Fl-CoA) can be substituted for biotin-CoA followed by subsequent direct fluorescent detection of the labeled thiolation domain. (B) Solid phase 4'-phosphopantetheinylation assay using biotin-CoA. In vitro $4^{\prime}$-phosphopantetheinylation assays were carried out on plates coated with Pes $3_{\mathrm{AT}}(2 \mu \mathrm{g} / \mathrm{mL})$. Results given represent the mean $( \pm \mathrm{SE})$ of the experiment performed in triplicate. (C) Solid phase 4'-phosphopantetheinylation assay using fluoresceinCoA. 4'-Phosphopantetheinylation assays were performed in microwells coated with Pes $3_{\mathrm{AT}}(2 \mu \mathrm{g} / \mathrm{mL})$. Results given represent the mean $( \pm \mathrm{SE})$ of the experiment performed in triplicate. (D) Solid phase 4'phosphopantetheinylation of Pes $3_{\mathrm{AT}}$ using purified PPTase $(29 \mu \mathrm{g} ; 0.7$ $\mathrm{nmol})$ and PPTase cell lysate. Results given represent the mean $( \pm \mathrm{SE})$ of the experiment carried out in triplicate. associated with labeled carrier protein detection and expedite analysis, we attempted direct immobilization of reaction mixtures to microwells, subsequent to in vitro $4^{\prime}$-phosphopantetheinylation followed by visualization and absorbance detection. This approach was unsuitable for use with biotin-CoA reporter analogues as the biotin moiety exhibited high nonspecific binding to microwells thereby masking any possibility of detecting PPTase mediated Pes $3_{\mathrm{AT}}$ labeling (data not shown). However, the approach was successfully applied to in vitro 4'phosphopantetheinylation assays using a fluorescein-labeled $\mathrm{CoA}$ analogue whereby 3 -fold greater fluorescence was detectable in specimens containing PPTase, Fl-CoA and Pes $3_{\mathrm{AT}}$ compared to specimens containing Fl-CoA and Pes $3_{\mathrm{AT}}$ alone (Figure 5). Although extensive validation of this approach has 

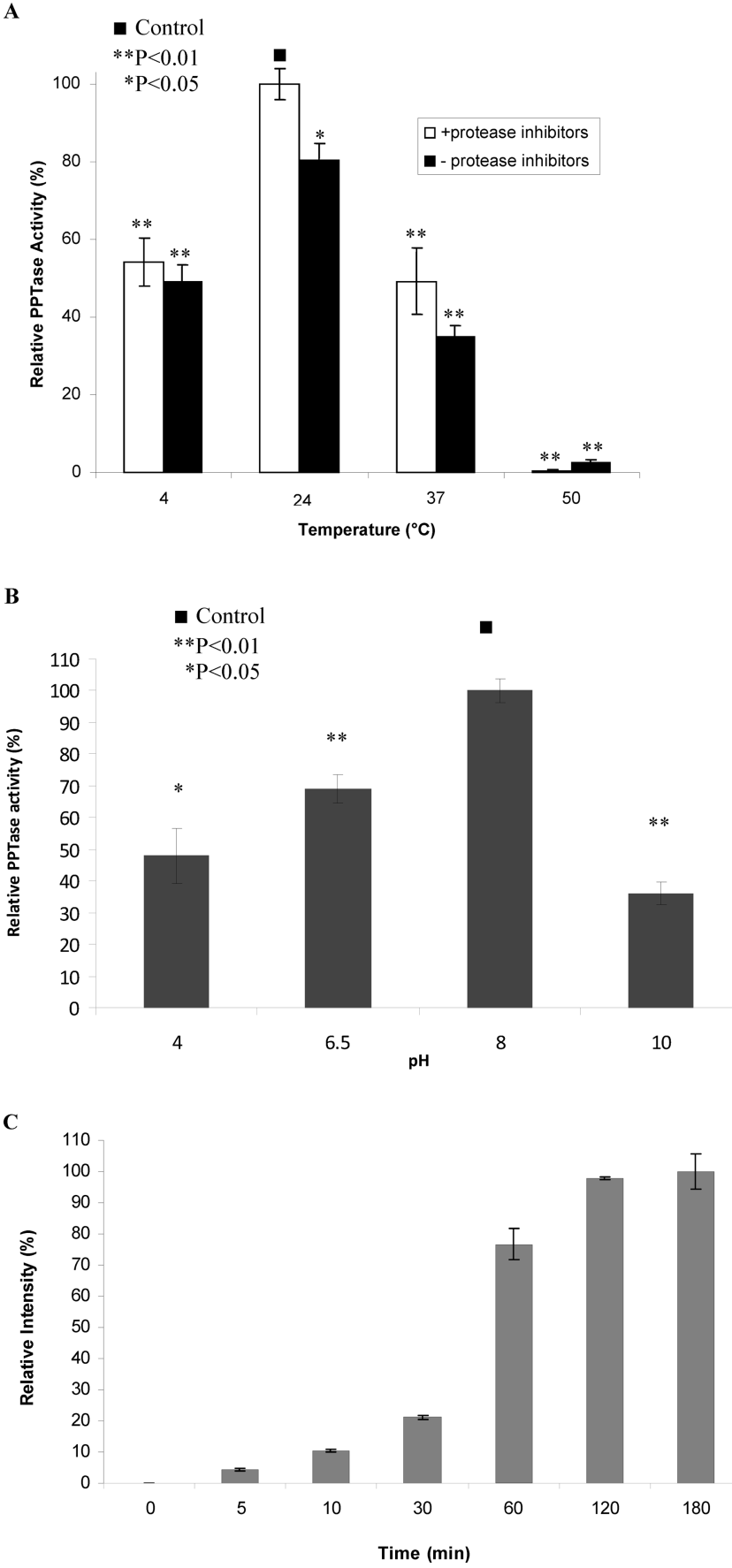

Figure 8. (A) The effect of temperature on PPTase activity in the presence and absence of protease inhibitors. Results given represent the mean $( \pm \mathrm{SE})$ of three individual experiments. Student's $t$ test was used to calculate $P$-values for the difference between the control (24 ${ }^{\circ} \mathrm{C}+$ protease inhibitors $)$ and the following conditions: $4{ }^{\circ} \mathrm{C}(+/-$ protease inhibitors $(P=0.003 ; P=0.0009)), 24{ }^{\circ} \mathrm{C}(-$ protease inhibitors $(P=0.03)), 37^{\circ} \mathrm{C}(+/-$ protease inhibitors $(P=0.005 ; P$ $=0.0002)$ ), and $50{ }^{\circ} \mathrm{C}( \pm$ protease inhibitors $(P=0.00001 ; P=$ $0.00002)$ ). (B) The effect of $\mathrm{pH}$ on PPTase activity. Results are expressed as percent (\%) relative to the highest level, i.e., $\mathrm{pH} 8.0$, and represent the mean $( \pm \mathrm{SE})$ of three individual experiments. Student's $t$ test was used to calculate $P$-values for the difference between the control (pH 8.0) and the following $\mathrm{pH}$ conditions: $4.0(P=0.01), 6.5(P=$ $0.008)$, and $10.0(P=0.0003)$. (C) The effect of reaction time on PPTase activity. Optimal reaction time is $2 \mathrm{~h}$; however, PPTasemediated protein modification is up to $75 \%$ complete by $1 \mathrm{~h}$.

not been undertaken, we propose that this hybrid assay format, involving solution phase, in vitro phosphopantetheinylation and reaction product immobilization for fluorescent detection, may find future application.
A number of groups have confirmed that proteins fused to either $\mathrm{T}$ domains of bacterial origin, or peptides derived from phage display, can be covalently tethered to immobilized CoA, and this observation has been proposed as a new strategy for protein array preparation $(9,20)$. However, to date, labeled pantetheine transfer to immobilized $\mathrm{T}$ domains, in either native or non-native configuration, has not been demonstrated. The 75 amino acid $\mathrm{T}$ domain used in our study is equivalent in size to other fungal and bacterial $\mathrm{T}$ domains but considerably longer than ybbR-like tags introduced by other groups (8). The use of the $\mathrm{T}$ domain of fungal (A. fumigatus) origin as a target for C-terminal labeling of Pes3 $3_{\mathrm{AT}}$ and N-terminal labeling of $\mathrm{T}-\mathrm{GstB}$, respectively, suggests that domain acceptor function is independent of position in the substrate protein. We have observed that purified Pes $3_{\mathrm{AT}}$ or T-GstB can be stably and irreversibly attached to microwells, blocked to minimize nonspecific binding, and followed by PPTase-mediated biotinylation or fluorescent labeling using either biotin-CoA or fluorescein-CoA. This finding represents a new strategy for assessment of both $\mathrm{T}$ domain functionality and PPTase activity determination and potentially for the assessment of PPTase/ AcpS/Sfp inhibitors, which have been proposed as potential drug targets (14).

Our data indicate that $0.33 \mu \mathrm{g}(4.4 \mathrm{pmol}) \mathrm{Pes} 3_{\mathrm{AT}}$ can be detected using $29 \mu \mathrm{g}(0.7 \mathrm{nmol})$ of recombinant PPTase (in either purified or crude form) in the presence of biotin-CoA via solid phase phosphopantetheinylation. It also suggests that any conformational restriction due to Pes $3_{\mathrm{AT}}$ immobilization does not significantly impede phosphopantetheinylation. Moreover, chemoenzymatic detection is statistically significant $(P<$ 0.05 ) over protein labeling in the absence of recombinant PPTase. Importantly, we also demonstrate that the $\mathrm{T}$ domain derived from Pes $3_{\mathrm{AT}}$ can be fused to an unrelated protein and also be subjected to solid phase phosphopantetheinylation. This confirms the discrete functionality of the T domain and strongly suggests that they can be used as a fusion partners for unrelated proteins to facilitate targeted labeling procedures.

In order to optimise the in vitro $4^{\prime}$-phosphopantetheinylation assay and to further characterize PPTase activity, assays were performed at different reaction temperatures. Initial in vitro $4^{\prime}$ phosphopantetheinylation assays using the A. fumigatus encoded recombinant PPTase (2) were carried out at a reaction temperature of $37^{\circ} \mathrm{C}$; however, optimal PPTase activity occurs at 25 ${ }^{\circ} \mathrm{C}$ with $100 \%$ increase in the extent of Pes $3_{\mathrm{AT}}$ modification observed compared to that at $37{ }^{\circ} \mathrm{C}$. In vitro $4^{\prime}$-phosphopantetheinylation assays employing the use of the B. subtilis PPTase Sfp, were carried out at room temperature and $30{ }^{\circ} \mathrm{C}$, respectively $(6,13)$. Furthermore, the in vitro phosphopantetheinylation assays used to assess the affect of PPTase (AcpS) specific inhibitors on the ability of the B. subtilis AcpS to posttranslationally modify the ACP carrier protein were also performed at $25^{\circ} \mathrm{C}(14)$.

Subsequent to determination of optimal PPTase reaction temperature, the effect of $\mathrm{pH}$ on PPTase activity was also investigated and revealed that optimal PPTase activity was observed at $\mathrm{pH} 8.0(100 \%)$, with a significant decrease in PPTase activity to $45 \%, 65 \%$, and $35 \%$ for $\mathrm{pH} 4.0, \mathrm{pH} 6.5$, and $\mathrm{pH} 10.0$, respectively. These observations are in accordance with those for the in vitro phosphopantetheinylation assays used for B. subtilis AcpS type PPTase, which were also carried out at $\mathrm{pH} 8.0$ (14). However, a clear $\mathrm{pH}$ optimum at $\mathrm{pH} 6.0$ for the $B$. subtilis Sfp type PPTase, with activity reducing to less than $20 \%$ of the optimum $\mathrm{pH}$ for $\mathrm{pH} 5.0$ and $\mathrm{pH} 7.0$, respectively, has been reported (3). Thus, it is clear that optimal reaction conditions should be established for each specific PPTase or equivalent AcpS/Sfp enzyme. 
In summary, we have demonstrated that solid phase in vitro 4'-phosphopantetheinylation, using either biotin- or fluoresceinCoA substrate analogues, of fungal thiolation domains in native or non-native configuration is possible. Moreover, we have conclusively shown that the solid phase assay format presents a new strategy for determination of PPTase activity, which is superior to current approaches and highly likely to be compatible with high-throughput screening systems for PPTase inhibitor identification. We also suggest that solid phase $4^{\prime}$-phosphopantetheinylation may be compatible with the ongoing search for peptide mimotopes, in part via phage display, of $\mathrm{T}$ domain functionality $(21,22)$.

\section{ACKNOWLEDGMENT}

We are grateful to both the Irish Higher Education Authority - Programme for Research in Third Level Institutions (PRTLICycle 3) and Enterprise Ireland Proof of Concept Scheme (EI/ PC/2006/379) which provided funding for this work.

Supporting Information Available: Experimental procedures and results relating to the synthesis efficiency of biotinCoA. This material is available free of charge via the Internet at http://pubs.acs.org.

\section{LITERATURE CITED}

(1) Mootz, H. D., Schorgendorfer, K., and Marahiel, M. A. (2002) Functional characterization of 4'-phosphopantetheinyl transferase genes of bacterial and fungal origin by complementation of Saccharomyces cerevisiae lys5. FEMS Microbiol. Lett. 213, 5157.

(2) Neville, C. M., Murphy, A., Kavanagh, K., and Doyle, S. (2005) A 4'-phosphopantetheinyl transferase mediates non-ribosomal peptide synthetase activation in Aspergillus fumigatus. ChemBioChem 6, 679-685.

(3) Quadri, L. E., Weinrab, P. H., Lei, M., Nakano, M. M., Zuber, P., and Walsh, C. T. (1998) Characterization of Sfp, a Bacillus subtilis phosphopantetheinyl transferase for peptidyl carrier protein domains in peptide synthetases. Biochemistry 37, 15851595.

(4) Mofid, M. R., Finking, R., and Marahiel, M. A. (2002) Recognition of hybrid peptidyl carrier proteins/acyl carrier proteins in nonribosomal peptide synthetase modules by the 4'phosphopantetheinyl transferases AcpS and Sfp. J. Biol. Chem. 277, 17023-17031.

(5) Weissman, K. J., Hong, H., Oliynyk, M., Siskos, A. P., and Leadlay, P. F. (2004) Identification of a phosphopantetheinyl transferase for erythromycin biosynthesis in Saccharopolyspora erythraea. ChemBioChem 5, 116-125.

(6) La Clair, J. J., Foley, T. L., Schegg, T. R., Regan, C. M., and Burkart, M. D. (2004) Manipulation of carrier proteins in antibiotic biosynthesis. Chem. Biol. 11, 195-201.

(7) Yin, J., Lin, A. J., Buckett, P. D., Wessling-Resnick, M., Golan, D. E., and Walsh, C. T. (2005) Single-cell FRET imaging of transferrin receptor trafficking dynamics by Sfp-catalyzed, sitespecific protein labelling. Chem. Biol. 12, 999-1006.

(8) Yin, J., Straight, P. D., McLoughlin, S. M., Zhou, Z., Lin, A. J., Golan, D. E., Kelleher, N. L., Kolter, R., and Walsh, C. T. (2005) Genetically encoded short peptide tag for versatile protein labeling by Sfp phosphopantetheinyl transferase. Proc. Natl. Acad. Sci U.S.A. 102, 15815-15820.
(9) Yin, J., Liu, F., Xiaohua, L., and Walsh, C. T. (2004) Labeling proteins with small molecules by site-specific postranslational modification. J. Am. Chem. Soc. 126, 7754-7755.

(10) Shute, T. S., Matsushita, M., Dickerson, T. J., La Clair, J. J., Janda, K. D., and Burkart, M. D. (2005) A site-specific bifunctional protein labelling system for affinity and fluorescent analysis. Bioconjugate Chem. 16, 1352-1355.

(11) Yin, J., Lin, A. J., Golan, D. E., and Walsh, C. T. (2006) Site-specific protein labeling by Sfp phosphopantetheinyl transferase. Nat. Protoc. 1, 280-285.

(12) Clarke, K. M., Mercer, A. C., La Clair, J. J., and Burkart, M. D. (2005) In vivo reporter labeling of proteins via metabolic delivery of coenzyme A analogues. J. Am. Chem. Soc. 127, 12341235.

(13) McLoughlin, S. M., Mazur, M. T., Miller, L. M., Yin, J., Liu, F., Walsh, C. T., and Kelleher, N. L. (2005) Chemoenzymatic approaches for streamlined detection of active site modifications on thiotemplate assembly lines using mass spectrometry. Biochemistry 44, 14159-14169.

(14) Joseph-McCarthy, D., Parris, K., Huang, A., Failli, A., Quagliato, D., Dushin, E. G., Novikova, E., Severina, E., Tuckman, M., Petersen, P. J., Dean, C., Fritz, C. C., Meshulam, T., DeCenzo, M., Dick, L., McFadyen, I. J., Somers, W. S., Lovering, F., and Gilbert, A. M. (2005) Use of structure-based drug design approaches to obtain novel anthranilic acid acyl carrier protein synthase inhibitors. J. Med. Chem. 48, 7960-7969.

(15) Carberry, S., Neville, C. M., Kavanagh, K. A., and Doyle, S. (2006) Analysis of major intracellular proteins of Aspergillus fumigatus by MALDI mass spectrometry: Identification and characterisation of an elongation factor 1B protein with glutathione transferase activity. Biochem. Biophys. Res. Commun. 341, 1096-1104.

(16) Burns, C., Geraghty, R., Neville, C., Murphy, A., Kavanagh, K., and Doyle, S. (2005) Identification, cloning, and functional expression of three glutathione transferase genes from Aspergillus fumigatus. Fungal Genet. Biol. 42, 319-327.

(17) Reeves, E. P., Reiber, K., Neville, C., Scheibner, O., Kavanagh, K., and Doyle, S. (2006) A nonribosomal peptide synthetase (pes1) confers protection against oxidative stress in Aspergillus fumigatus. FEBS J. 273, 3038-3053.

(18) Hansen, R. E., Østergaard, H., Nørgaard, P., and Winther, J. R. (2007) Quantification of protein thiols and dithiols in the picomolar range using sodium borohydride and 4,4'-dithiodipyridine. Anal. Biochem. 363, 77-82.

(19) Haan, C., and Behrmann, I. (2007) A cost effective noncommercial ECL-solution for Western blot detections yielding strong signals and low background. J. Immunol. Methods 318, 11-19.

(20) Wong, L. S., Thirlway, J., and Micklefield, J. (2008) Direct site-selective covalent protein immobilization catalyzed by a phosphopantetheinyl transferase. J. Am. Chem. Soc. 130, 1245612464.

(21) Zhou, Z., Koglin, A., Wang, Y., McMahon, A. P., and Walsh, C. T. (2008) An eight residue fragment of an acyl carrier protein suffices for post-translational introduction of fluorescent pantetheinyl arms in protein modification in vitro and in vivo. J. Am. Chem. Soc. 130, 9925-9930.

(22) Zhou, Z., Cironi, P., Lin, A. J., Xu, Y., Hrvatin, S., Golan, D. E., Silver, P. A., Walsh, C. T., and Yin, J. (2007) Genetically encoded short peptide tags for orthogonal protein labeling by Sfp and AcpS phosphopantetheinyl transferases. ACS Chem. Biol. 2, 337-346.

BC900071J 